\title{
Harnessing Digital Tools in Collaborative Inquiry for Contemporary Interpretation of the Pancasila
}

\author{
Christine Edith Pheeney \\ Charles Darwin University \\ Darwin, Australia \\ christineida@ozemail.com.au
}

\begin{abstract}
Twenty-three teachers, representative of Indonesia's religious and cultural diversity, were recruited in an online interregional collaborative inquiry (OICI) of the Pancasila Indonesia's founding values. This undertaking matches calls from the highest levels of Indonesian government for a Mental Revolution, encouraging citizens to dig into cultural roots to address sectarian conflict. Google Hangouts On Air afforded teachers joining video calls on their digital devices with screensharing of 'Conflict Resolution Education Module' [25] and a facilitator fostering discussion. A Google Classroom afforded asynchronous sharing. The inquiry evolved organically fitting technology mediation to daily living. Harnessing social media to teacher learning facilitated an enactment and deeper understanding of the Pancasila and peace. This paper reviews computer-human interaction (CHI) related to recruitment and engaging in the OICI, contributing to the growing field, by describing 'control, context and communication' constructs negotiated to enable empowering digital transformation for teacher needs. As such, it documents a component of the research project still underway, that studies the teachers' OICI experiences and how this supports or hinders contemporary interpretation of the Pancasila.
\end{abstract}

\section{Author Keywords}

Collaborative Inquiry; Indonesia; Computer-Human Interaction; Teacher Learning.

ACM Classification Keywords

H.5.m. Information Interfaces and Presentation (e.g. HCI): Miscellaneous

Permission to make digital or hard copies of part or all of this work for personal or classroom use is granted without fee provided that copies are not made or distributed for profit or commercial advantage and that copies bear this notice and the full citation on the first page. Copyrights for thirdparty components of this work must be honored. For all other uses, contact the Owner/Author.

CHIuXiD'19, April 1-9, 2019, Jakarta, Surabaya, Bali, Indonesia (C) 2019 Copyright is held by the owner/author(s).

ACM ISBN 978-1-4503-6187-3/19/04.

https://doi.org/10.1145/3328243.3328259

\section{INTRODUCTION AND BACKGROUND}

As Indonesia faces sectarian conflict, institutions are directed 'to animate [embody] the Pancasila values and put them into practice in daily life' [24]. Analysis of the Pancasila reveals underlying cultural heritages engaging collaborative deliberations (or inquiries) to meet opportunities and challenges of life evident in village democratic contexts [19]. Nation building efforts, impacted by various internal and external influences, have not yet delivered such in modern governance. Rather, formal institutions largely override and hegemonise dynamic cultural inquiries and interactions [9]. Decentralisation efforts introduced to enhance the relationship between state systems and society [15] bring calls for coordination of interregional collaboration to counter local egoism [9]. Pragmatically, teachers are in a pivotal position to facilitate universal respect and inclusivity in increasingly diverse classrooms [6]. However Indonesian teachers struggle to mobilise cultural wisdom [11] with cultural literacy deficits [31] due to challenges in providing professional development, especially to remote locations [23]. Developing 'communities of practice' is discussed by Lave and Wenger [18], who describe the process of learning occurring in social situations, where structured participation frameworks can provide the conditions to engage even peripheral participants. Datnow [4] asserts teachers need supportive structures and cultures to collaborate. Hargreaves [4] describes collaborative culture characteristics as being established through and in working together with open participation. Söderström, Hamilton, Dahlgren and Hult [27] prescribe a centralised purpose to develop participation. Concurrently, 'collaborative inquiry' is increasingly used internationally in education research practice, where teachers work together on common challenges, discuss and analyse relevant information to undertake needs-based activities [5]. Concomitantly, postcolonial and transformative learning discourses commend collaborative inquiry as facilitating learning that validates and is more inclusive of diversity $[16$, 12] to transform problematic frames of reference [28]. Successively digital connectivity tools emerge with facility to develop collaborative communities and maximise reflective opportunities [7]. Garrison [8] asserts commitment to personal reflection and critical discourse are inherent in community inquiries and produce gains of metacognitive awareness through sustained discourse. Simultaneously digital tools offer broad accessibility [23] and the Conflict 
Resolution Education Module is available to scaffold Indonesian teachers an online interregional collaborative inquiry to enact the Pancasila [25]. Sari [23] reports that Indonesian teachers can learn and collaborate with flexibility with others regardless of time and place facilitated by social media tools. Pheeney and Klieve [21] discuss the potential of social media to empower teachers in undertaking professional learning of local content needing to be activated.

Against this backdrop a unique research opportunity presents. While online communities are now common globally and the Pancasila perpetually arouses waves of discourse in Indonesia, to date, focus on the representative scope of Indonesia as a unit of analysis has been largely absent from qualitative studies of Indonesian teachers. The research question posed is: "What are the experiences of Indonesian teachers engaging in an interregional online collaborative inquiry of the Pancasila and how do these experiences support or hinder contemporary interpretation of the Pancasila?". Study of the teachers' experiences is the focus of a research project still underway by the author. This paper reports on experiences related to the teachers' computer-human interactions (CHI) harnessing digital tools in recruitment and participation within the OICI. Awareness of teachers' CHI within the OICI are useful to:

a) software engineers and developers for requirements, design and evaluation related to mobile learning;

b) promote discussion in education to analyse activity and examining interactions between people and technology; and

c) assist dialogue between education and software enclaves to tailor empowering digital transformation.

\section{METHOD}

In conducting the OICI and study of the teachers' experiences, the approach taken is explicitly guided by a gotong royong ethos. Gotong royong is described as cooperative, community service that jointly shoulders responsibilities and shares resources for interdependent relational living [14]. This approach correlates to internationally discussed 'collaborative inquiry' applying 'reciprocity' and 'authenticity' principles to govern activities [1]. Accordingly, recruitment, engagement, recording, analysis and sharing of data are designed to facilitate "mutual sharing of power, valuing of expertise and generation of genuine understanding of the experiences' [1]. Collaborative inquiry amongst teachers of diverse backgrounds, was engaged within synchronous sessions and asynchronous forums. Within the activities the author/lead researcher functioned in co-inquirer-facilitator and observer roles aligned with collaborative inquiry principles and afore described gotong royong ethos. Transcripts from the collaborative inquiry sessions and forums, along with responses to open ended interview questions as qualitative techniques are selected to explore the teachers' ideas, feelings, perspectives and experiences. Anecdotal notes of observations and impromptu interactions also provide insight into teachers' experiences. Within this paper these are in studied to describe, understand and analyse, details and factors related to $\mathrm{CHI}$ and harnessing of the digital tools in the OICI. Sharples, Vavoula and Taylor's [26] Theory of Learning for the Mobile Age provides a way to organise the teachers experiences. Sharples et al [26] assert learning occurs amidst the 'dynamic system that comprises people and technology in continual flux' (p.4) and suggest investigating semiotic and technological layers of learning. In this paper, Sharples et al's [26] control, context and communication constructs of the technological layer are utilised to present the teachers' $\mathrm{CHI}$ experiences. To ensure authenticity the researcher undertakes member checking after receiving transcripts of sessions and interviews (back from external transcriber) and maintains regular contact with teachers in the process of interpreting data. Engaging diverse teacher participation was organised in conjunction with regional partners and details related to recruitment are now described.

\section{Recruitment/Participation}

OICI participation aimed for voluntary recruitment of two groups of ten teachers, including the researcher as a coinquirer teacher in each group. To facilitate engagement of diversity, the study aimed to recruit teachers from various backgrounds, inclusive of representative scope of Indonesia's population: - members of ethnic cultures (from each of the eight geophysical regions), indigenous and transmigrants; followers of diverse religions (recognised in government policy), early to late teaching career, varied age, females and males, formal - non formal teaching activities, teaching at public - private schools; and honourary to permanent employment statuses. The unifying aspects of teaching role in primary (elementary) school age education and interest in the research focus of collaborative inquiry of the Pancasila. Regional contacts assisted gathering teachers to attend a presentation of the OICI opportunity in each location. After hearing details and considering personal availability, volunteering teachers completed an agreement with the lead researcher to join the OICI. Voluntary participation included agreement that teachers' phones or computers allow a dynamic CHI system of communication. The sessions were scheduled to be one hour in duration, outside of formal teaching hours. Given three time zones across Indonesia, this time was earlier or later in the day relating to teacher location. Teachers had freedom to withdraw at any time without any impact/consequence to themselves. This freedom was exercised and is reflected in overall recruitment (signed agreements) of twenty-three, fluctuating to reach the research goal of eighteen recruits to be co-inquirers with lead researcher. When discussing reporting options of the study, the teachers considered use of their names as appropriate. This reflects relational authenticity and accountability principles/gotong royong ethos being applied. Table 1 lists OICI members with a summary of their diverse backgrounds. 
Proceedings of CHluXiD 2019 - The $5^{\text {th }}$ ACM In Cooperation International Conference in $\mathrm{HCl}$ and UX

\begin{tabular}{|c|c|c|c|c|c|}
\hline $\begin{array}{l}\text { Geo-physical } \\
\text { Region }\end{array}$ & Teaching Location & $\begin{array}{l}\text { Ethnic Culture \& } \\
\text { Religion }\end{array}$ & $\begin{array}{l}\text { Gender, } \\
\text { Age }\end{array}$ & School Sector, Discipline, Years of Teaching & Name \\
\hline Sumatra & City of Banda Aceh & Aceh, Muslim & Female, 27 & National; Grade 5, 5 years & Yoes \\
\hline Jawa & Village of Bantan & $\begin{array}{l}\text { Buduy, Tribal - } \\
\text { Wiwitan }\end{array}$ & Male. 44 & $\begin{array}{l}\text { Informal; Life skills incl. character, cultivation, building; } \\
\text { parent - } 20+\text { years }\end{array}$ & Arwan \\
\hline Kalimantan & $\begin{array}{l}\text { Village of Simpang } \\
\text { Jela }\end{array}$ & Banjar, Muslim & Male, 27 & National; Grade 6,4 years & Reza \\
\hline Kalimantan & City of Pontianak & $\begin{array}{l}\text { Tiong hoa, } \\
\text { Buddhist }\end{array}$ & Female, 27 & Private; Grade 6, 7 years & Feni \\
\hline Bali & City of Denpasar & Bali Mahajit, Hindu & Female * $^{*}$ & $\begin{array}{l}\text { National; Grade 3; withdrew - employment change, recruited } \\
\text { Yoni to replace) }\end{array}$ & Yuli \\
\hline Bali & City of Denpasar & Bali Aja, Hindu & Female, 22 & National; Grade 3, 3 months & Yoni \\
\hline $\begin{array}{l}\text { Nusa Tenggara } \\
\text { Timur (NTT) }\end{array}$ & $\begin{array}{l}\text { Village hamlet } \\
\text { Ombardee }\end{array}$ & Wewewa, Catholic & Male, 29 & National; Grade 5, 5 years & Fedi \\
\hline Sulawesi & City of Makassar & Bugis, Muslim & Female, 38 & National; varied roles - Grade 2 \& teacher trainer; 13 years & Rini \\
\hline Maluku & City of Ambon & $\begin{array}{l}\text { Java Ambon, } \\
\text { Muslim }\end{array}$ & Female, 33 & National; Grade 2, 11 years & Siti \\
\hline Papua & City of Jayapura & Papua, Protestant & Female, 34 & Private; English Teacher to Grade 4,5,6; 1 year 4 months & Agustina \\
\hline Jawa & City of Malang & Java, Protestant & Male, 34 & Private; Grade 4, 9 years & Daniel \\
\hline $\begin{array}{l}\text { Northern } \\
\text { Territory }\end{array}$ & $\begin{array}{l}\text { Outer Darwin, } \\
\text { Regional Australia }\end{array}$ & $\begin{array}{l}\text { Australian, } \\
\text { Christian }\end{array}$ & Female, 45 & $\begin{array}{l}\text { PhD Candidate, Australian National \& Private primary; } \\
\text { volunteer in Indonesian Education Activities; } 20 \text { years, }\end{array}$ & Christine \\
\hline Sumatra & City of Medan & $\begin{array}{l}\text { Batak Toba, } \\
\text { Protestant }\end{array}$ & Female, 36 & Private; Grade $5 ; 10$ years & Darma \\
\hline Jawa & City of Tasikmalaya & Sunda, Muslim & Female, 40 & National; Grade 4; 14 years & Intan \\
\hline Kalimantan & City of Pontianak & $\begin{array}{l}\text { Tiong hoa, } \\
\text { Buddhist }\end{array}$ & Male, 37 & International; Grade 4; 6 years & Jay \\
\hline Bali & City of Denpasar & Bali Aja, Hindu & Female * $^{*}$ & $\begin{array}{l}\text { National; Grade } 1^{*} \text { (withdrew before start as newly engaged, } \\
\text { recruited Komang) }\end{array}$ & Eka \\
\hline Bali & City of Denpasar & Bali Mahajit, Hindu & Female, 22 & National - Honour employment status; Grade 1, 3 months & Komang \\
\hline NTT (Sumba) & $\begin{array}{l}\text { Village Hamlet of } \\
\text { Ombaradee }\end{array}$ & $\begin{array}{l}\text { Wewewa, } \\
\text { Protestant }\end{array}$ & Female, 29 & National - Honour Employment status; Grade 5; 3 years & Yohana \\
\hline Sulawesi & Gowa & $\begin{array}{l}\text { Duri dan } \\
\text { Moronene, Muslim }\end{array}$ & Male, 26 & $\begin{array}{l}\text { National; SOSE - Senior Highschool, status changed, } \\
\text { previously primary in Papua, } 3 \text { years }\end{array}$ & $\mathrm{Am}$ \\
\hline Sulawesi & $\begin{array}{l}\text { Village Hamlet of } \\
\text { Toraja }\end{array}$ & Sunda, Protestant & Male, 36 & National, Religious Instruction, primary; 1 year & Iwan \\
\hline Maluku & City of Ambon & Catholic * & Female * & $\begin{array}{l}\text { Private * Death of Mother on day of } 1^{\text {st }} \text { session, didn't re- } \\
\text { engage; LR recruited Rusna to replace }\end{array}$ & Tia \\
\hline Maluku & City of Ambon & Maluku, Muslim & Female, 41 & Private; Grade $5 ; 12$ years & Rusna \\
\hline Papua & Region of Sentani & $\begin{array}{l}\text { Nimboran, } \\
\text { Protestant }\end{array}$ & Female, 40 & Private; Grade 1; 6 years & Nella \\
\hline Jawa & City of Malang & Javanese & Male * & $\begin{array}{l}\text { National, Grade } 6 \text { * Issues with phone, withdrew after } 2 \\
\text { session; LR recruited Daniel to replace }\end{array}$ & Hasnuddin \\
\hline
\end{tabular}

Table 1. List of OICI members and backgrounds

Teacher extra commitments or connectivity issues brought about flexible attendance and addition of extra times - this resulted in the two intended groups becoming blurred as the teachers joined various running times of the four "Conflict Resolution Education Module" [25] video segments scaffolding sessions. In must be noted, that while teacher's recruitment from diverse backgrounds is a feature of the research design to enable engagement with diversity, subjectivities of each teacher's experience aren't intended to be used to make generalisations - it is a limited sample. The study explores experiences of these Indonesian teachers, in this OICI.

\section{FINDINGS}

In exploring the teachers experiences specific to $\mathrm{CHI}$, in the OICI, the findings are organised utilising Sharples et al [26] control, context and communication constructs. The details are set out in tables of each construct and register the specifics of the negotiation. This facilitates understanding of the factors and relationships involved in harnessing digital technology.

\section{Control}

In order to conduct the OICI the lead researcher proposed a base format. This format underwent negotiation to actualise and enable functionality, the details are shown in Table 2. 
The teachers' experiences included negotiating control related to: recruiting, content, session timing, internet connectivity, social conventions, computer device, platform, participation and attitudes. In summary, teacher recruitment was relationally negotiated, between lead researcher, regional contacts, teachers and application of technology in facilitating introductions in physical and virtual meetings. Engagement required varying amounts of support to load platforms and enter OICI sessions on digital devices. Some teachers did not optimise personal control in relation to meeting social conventions of centring face in camera view, ensuring adequate lighting and minimal background noise. Teachers' attitudes were positive, shown in high engagement and conversational remarks, composition of content and willingness to be flexible. Internet connectivity and extra school commitments impacted participation and is largely out of teachers' control. Suggestions of formalising institutional support for session timings were given.

\begin{tabular}{|c|c|c|}
\hline Experiences & Proposed Format & Actualised Details \\
\hline $\begin{array}{l}\text { Recruiting - } \\
\text { representatives } \\
\text { of Indonesia's } \\
\text { dispersed, } \\
\text { cultural, } \\
\text { religious, } \\
\text { formal/non- } \\
\text { formal teachers }\end{array}$ & $\begin{array}{l}\text { Researcher visit to sites corresponding } \\
\text { to research design. Site contact set up } \\
\text { presenting of OICI opportunity, inviting } \\
\text { representatives } \\
\text { - Volunteerism - joining presentation \& } \\
\text { OICI } \\
\text { - Recruitment subject to availability of } \\
\text { internet network, device \& commitment }\end{array}$ & $\begin{array}{l}\text { - } \\
\text { Researcher visited all but } 1 \text { site - Papua site was off limits for researcher visit. Papua Recruitment } \\
\text { occurred via contact setting up video call to Papuan schools. } \\
\text { Volunteer Teachers recruited after hearing OICl opportunity. } \\
4 \text { teachers withdrew. } 2 \text { withdrew before sessions started, these original recruits organised } \\
\text { replacements independently; } 2 \text { more withdrew without explanation in week } 1.3 \text { more were } \\
\text { recruited after week } 2 \text { - } 2 \text { of these were present at regional OICI presentation, } 3^{\text {rd }} \text { was recruited via } \\
\text { a different contact using video call sharing of OICl opportunity. }\end{array}$ \\
\hline $\begin{array}{l}\text { Content } \\
\text { Conflict } \\
\text { Resolution } \\
\text { Education } \\
\text { Module }\end{array}$ & $\begin{array}{l}\text { Use of module resources (screen shared in } \\
\text { Google Hangouts On Air }-4 \text { videos }-12 \\
\text { minutes for each week) to stimulate inquiry } \\
\text { focus and interaction. Comprised of: } \\
\text { stories, expert advice, questions, } \\
\text { classroom practice example, animations }\end{array}$ & $\begin{array}{l}\text { Module stimulus was useful, with occasional technology glitches (non-functioning screen sharing or } \\
\text { distracting background noises) } \\
\text { - Provided scaffold to explore understandings of the Pancasila } \\
\text { - Built shared vocabulary and lead researcher initiated relational reciprocity from prompt in module, incl. } \\
\text { teachers sharing and discussing school scenarios/efforts/context }\end{array}$ \\
\hline $\begin{array}{l}\text { Internet } \\
\text { Connectivity }\end{array}$ & $\begin{array}{l}\text { Existing internet networks; Data credit } \\
\text { finances supplied by research funds for the } \\
\text { collaborative sessions and interview }\end{array}$ & $\begin{array}{l}\text { Most teachers appreciative of data credit provision, } 3 \text { declined and used independent resources/ finances. } \\
\text { Variable Network function - some variability uncontrollable to the user (weather) and some controllable by } \\
\text { the individual user - location during scheduled session known to be good internet connectivity; }\end{array}$ \\
\hline $\begin{array}{l}\text { Participation - } \\
4 \quad \text { scheduled } \\
\text { synchronous } \\
\text { sessions; } \\
\text { asynchronous } \\
\text { facility, survey } \\
\text { \& interview }\end{array}$ & $\begin{array}{l}\text { Proposed - } 2 \text { groups of } 10-\text { Tuesday \& } \\
\text { Thursday schedules. Agreement requested } \\
\text { by researcher, considering school environ } \\
\& \text { family commitments as able to join, } \\
\text { Preliminary mitigation to absenteeism was } \\
\text { supply links to recorded sessions and } \\
\text { request to view independently. }\end{array}$ & $\begin{array}{l}\text { Some external school conditions overrode commitment to } \mathrm{OICl} \text { - extra staff meetings related to national } \\
\text { exam or similar; staff travelling to another staff member's wedding } \\
\text { Some personal issues effected attendance - mother of teacher died in first week of OICI; Teacher family } \\
\text { member ill or Teacher ill (including hospitalisation for } 3 \text { teachers over the scheduled sessions) } \\
\text { Some technical issues (inaccuracy with invitation acceptance and/or sending). Given the above and low } \\
\text { interest of absentees viewing recordings, extra sessions were added. Result: synchronous groups were } \\
\text { not distinct entities of full representation, but smaller group size did enable greater participation. }\end{array}$ \\
\hline $\begin{array}{l}\text { Participation - } \\
\text { synchronised } \\
12.30 \mathrm{pm} \text { WIB; } \\
1.30 \mathrm{pm} \text { WITA; } \\
\text { 2.30pm WIT } \\
\text { Indonesia has } 3 \\
\text { time zones }\end{array}$ & $\begin{array}{l}\text { Researcher prompted this specific time } \\
\text { after discussion with recruits in all locations, } \\
\text { it was deemed most available and } \\
\text { individually discussed for suitability and } \\
\text { availability. }\end{array}$ & $\begin{array}{l}\text { Local autonomy impacts school hours - not a standard schedule across the nation (incl. } 5 / 6 \text { day school } \\
\text { week). }{ }^{* *} \text { participation reduced for } 3 \text { teachers with rotational school schedule }- \text { not conveyed at recruitment } \\
\text { - these teachers taught mornings for } 2 \text { weeks of the } \mathrm{OICl} \text { and afternoons for } 2 \text { weeks of the OICl (high } \\
\text { population districts often use a school venue for } 2 \text { cohorts in rotation). } \\
\text { Scheduled times were easier for teachers on site at schools as non-contact time; others joining from their } \\
\text { homes often had compromised focus. Catch-up sessions were scheduled in response to teachers } \\
\text { requested times, incl. on weekends. }\end{array}$ \\
\hline $\begin{array}{l}\text { Teacher } \\
\text { owned } \\
\text { devices }\end{array}$ & $\begin{array}{l}\text { Suggested by researcher for autonomous } \\
\text { teacher participation }\end{array}$ & $\begin{array}{l}\text { Some participation hindered by device power or functional issues - the phones needed to be fully charged } \\
\text { or charging while using and positioned with internet receptivity. Most teachers chose to use their mobile } \\
\text { device (some used a Personal Computer - PC - some of the time). }\end{array}$ \\
\hline $\begin{array}{l}\text { Platform } \\
\text { Google } \\
\text { Hangouts On } \\
\text { Air - Free } \\
\text { online tool for } \\
10 \text { members - } \\
\text { video, audio, } \\
\text { visual, chat, } \\
\text { interactivity - } \\
\text { a/synchronous } \\
\text { functionality; }\end{array}$ & $\begin{array}{l}\text { Selected by researcher after comparison to } \\
\text { other social media video platforms } \\
\text { Google Hangouts On Air required } \\
\text { installation of Google Hangouts - as base } \\
\text { app for teachers; lead researcher used } \\
\text { Google Hangouts On Air) } \\
\text { Selected as compatible with characteristics } \\
\text { of typical Indonesian teacher phone } \\
\text { ownership - low memory capacity, pre- } \\
\text { existing installation on most android phones } \\
\text { Google classroom also required very little } \\
\text { memory space with the capacity described } \\
\text { (left column). } \\
\text { These apps were selected for teachers to } \\
\text { easily reproduce or conduct a future OICl } \\
\text { without the researcher's facilitation or } \\
\text { specific equipment (incl. without fees that } \\
\text { some other video conferencing software } \\
\text { has) and without extra distractions that } \\
\text { some other feed apps have. }\end{array}$ & $\begin{array}{l}\text { The researcher assisted set up of Google Hangouts and Google Classroom on teacher's mobile device. } \\
\text { Set up and testing was usually problem free (with smaller numbers and immediate lead researcher one- } \\
\text { on-one support). However, Google Hangouts has some features that are further explored in } \\
\text { 'communication' construct section below relating to adjusting for some during the actual OICl. } \\
\text { The combination of Google Hangouts and Google Classroom allowed both direct interaction and time and } \\
\text { space to develop ideas, questions, and foster reflection, with stimulus materials and teachers' interaction } \\
\text { available for time/place flexible access. These tools facilitated community building, with a place to respond, } \\
\text { ask questions, share and engage in discussion. Teachers commented that inactive notification settings } \\
\text { or busyness produced limited interaction occurred in google classroom, and that having the resources was } \\
\text { beneficial and utilised with limitless accessibility and use with classes. } \\
\text { Whatsapp (a popular messaging app) was uses at times to assist teachers to post to google classroom or } \\
\text { when internet was not strong enough for google hangouts. Or when teachers didn't respond to Google } \\
\text { posts (usually because notifications for this app weren't active). } \\
\text { The set-up period was between } 3 \text { and } 36 \text { days before the actual running of the collaborative inquiry (due } \\
\text { to dispersed site visits). This was problematic - some teachers forgot how to respond to permissions } \\
\text { (entering each Google Hangouts On Air session required permission and inappropriate response meant } \\
\text { inability to join). This inappropriate response arose with comprehension issues: Google Hangouts base } \\
\text { set up for microphone and video permissions had positive response on left side and also used colour } \\
\text { coding (green/red for positive/negative permissions) and was presented in Indonesian. The 'Google } \\
\text { Hangouts On Air' call permissions was on the right side, with no colour coding and use of English. }\end{array}$ \\
\hline $\begin{array}{l}\text { Social } \\
\text { Conventions - } \\
\text { Ensuring easy } \\
\text { identification } \\
\text { and optimal } \\
\text { position to } \\
\text { facilitate } \\
\text { effective, } \\
\text { friendly sharing }\end{array}$ & $\begin{array}{l}\text { Use of Google Hangouts On Air control } \\
\text { panel to mute teachers when not talking if } \\
\text { background noises were distracting; } \\
\text { Informally introduced to 'radio-control' } \\
\text { speech to alert handover to specific next } \\
\text { speaker } \\
\text { Prompt for lighting and face positioning }\end{array}$ & $\begin{array}{l}\text { Many teachers had loud background noises even with headphone mics. Noises incl. - chickens, trucks \& } \\
\text { cars, toddlers cries, internet static, interruptions and public announcements. We all became aware that } \\
\text { the muting control panel of google hangouts on air had limited functionality - 'muting' by lead researcher } \\
\text { only impacted lead researcher -noises were still heard by participants (and recorded). Some teachers } \\
\text { suggested others to use headset. One teacher muted herself, alerting lead researcher to this option. } \\
\text { Muting became a shared responsibility, with lead researcher instructing those unfamiliar with switching } \\
\text { off/on microphone icon. } \\
\text { Despite frequent prompts to source ideal lighting and centre face, teachers were not attentive to optimal } \\
\text { face sharing in videocalls }\end{array}$ \\
\hline Attitudes & $\begin{array}{l}\text { Volunteerism/Gotong } \\
\text { bringing engagement }\end{array}$ & $\begin{array}{l}\text { Volunteerism, cultural dispositions and personal interest provided base for positive attitudes related to } \\
\text { engagement in } \mathrm{OICl} \text {. }\end{array}$ \\
\hline
\end{tabular}

Table 2. Negotiation of CHI Construct Control - Proposed Format and Actualised Details. 
Proceedings of CHluXiD 2019 - The $5^{\text {th }}$ ACM In Cooperation International Conference in $\mathrm{HCl}$ and UX

\begin{tabular}{|c|c|c|}
\hline $\begin{array}{l}\text { Interaction } \\
\text { Properties }\end{array}$ & Planned Methodology & Actualised Details \\
\hline $\begin{array}{l}\text { Mutual } \\
\text { Knowledge }\end{array}$ & $\begin{array}{l}\text { Prompt teachers' sharing knowledge of Indonesia, } \\
\text { cooperative ethos, use of technology in presentation of } \\
\mathrm{OICl}\end{array}$ & $\begin{array}{l}\text { Teachers very responsive to 'Mouse Story' animation and sharing of } \mathrm{OICl} \text { vision. } \\
\text { Connected to mutual knowledge, teachers excited and curious to join and learn together. All } \\
\text { had a similar base knowledge of the Pancasila, but a variety of lived experiences related to } \\
\text { their diverse backgrounds and locations. }\end{array}$ \\
\hline $\begin{array}{l}\text { Shared } \\
\text { Objectives, }\end{array}$ & $\begin{array}{l}\text { Utilise Google Hangouts and Google Classroom to } \\
\text { develop, reflect and share ideas, questions, and foster } \\
\text { reflection, with stimulus (module) materials }\end{array}$ & $\begin{array}{l}\text { Teachers shared personal reasons to join and teaching goals. This quickly built community } \\
\text { and the OICI became a space where teachers shared and learnt from each other. }\end{array}$ \\
\hline $\begin{array}{l}\text { Communities } \\
\text { of Actors }\end{array}$ & $\begin{array}{l}\text { Representative target recruits of various cultural and } \\
\text { religious backgrounds. Working with regional contacts and } \\
\text { teachers' volunteerism. }\end{array}$ & $\begin{array}{l}\text { The teachers' comments showed their engagement within various groups and in various } \\
\text { roles. They shared as a) professional teachers talking about their students and school } \\
\text { colleagues; b) citizens and family members and members of religious - enthusiastic to } \\
\text { contribute their expertise and relational connections pertinent to dialogue. }\end{array}$ \\
\hline $\begin{array}{l}\text { Orientations } \\
\text { to study }\end{array}$ & $\begin{array}{lrr}\text { Facilitating } \quad \text { professional } & \text { and } & \text { background } \\
\text { (cultural/religious/experiential) } & \text { specific } & \text { sharing, } \\
\text { understanding and mutual support). } & & \end{array}$ & $\begin{array}{l}\text { This flowed remarkably naturally! Teachers were all very keen to share about themselves } \\
\text { and their experiences as well as offer advice and make observations and applications of } \\
\text { input they had received in the OICI. They came as individuals representing sub } \\
\text { communities and became a group with a shared story of common experience and mutual } \\
\text { shared active respect for Pancasila values and each other and Indonesia. }\end{array}$ \\
\hline Styles & $\begin{array}{l}\text { Facilitating nurturing relationships, providing input on } \\
\text { understanding human relationships as well as forum to } \\
\text { explore 'unity in diversity' as the goal of interpreting the } \\
\text { Pancasila. }\end{array}$ & $\begin{array}{l}\text { Teachers were very engaged in conversation, responding to questions and each other. In } \\
\text { responses they tended to make remarks about their similarities and differences. }\end{array}$ \\
\hline $\begin{array}{l}\text { Strategies of } \\
\text { Learning }\end{array}$ & $\begin{array}{l}\text { Lead researcher led transformative learning through } \\
\text { dialogue and module resources; collaborative inquiry } \\
\text { emphasising inclusive participation, co-constructing } \\
\text { knowledge, democratic and reciprocal relationships. }\end{array}$ & $\begin{array}{l}\text { Teachers reflected on how easy and natural it was to work with the } \mathrm{CHI} \text { in studying the } \\
\text { Pancasila together. Many teachers made remarks about how their perspective and/or } \\
\text { teaching practice had been transformed through engagement with each other and module } \\
\text { resources. }\end{array}$ \\
\hline
\end{tabular}

\section{Context}

The OICI emerged to be a supportive professional community realised/dependent upon human-computer interaction. Growing from a proposed idea, communities of actors acted upon mutual knowledge within mutually dependent shared objectives. These aspects of context are explored in Table 3, along with orientations to study, styles and strategies for learning as integral properties of the OICI. In summary, the teachers embraced the fluidity and mobility of the context. Professional, national identities, understandings and skills were built upon within the OICI. The teachers were reflective and thoughtful, sharing their diversity in the OICI context with their own devices facilitating.

\section{Communication}

Communication in the OICI was based upon a technological system of specific apps ('App' - a type of application software designed to run on a mobile device, such as a smartphone or tablet computer and provides specific services or functionality). Google Hangouts/Google Hangouts On Air and Google Classroom were selected to support communication in this study. Proposed format and negotiated actualised communication are described in Table 4. The greatest variance is seen in low asynchronous engagement. Intentional support to create a Google profile is shown as needed; along with more attention to ensuring understandability of lead researcher's written language (troublesome as language limitations as non-native Indonesian); user friendly app specifics, optimised facial recording and background noise cancelling functionality.

\section{Extra information relating to Google Hangouts and Google Hangouts On Air apps}

For the teachers there was little difference visually between Google Hangouts and Google Hangouts On Air, but there were a few differences in the app function that are important to the design of the OICI and research data collection. This includes that during session (live video conference call) the lead researcher uses a PC/IOS laptop with allowance to screenshare and with control panels for muting as well as visual controls to make the person speaking large for recording. Recording was a very useful feature to allow teachers who hadn't previously attended to view, and later comment asynchronously as well as anybody to re-watch the session and share the sessions with others.

\section{Teachers reflections of the $\mathrm{CHI}$}

Teachers interactive comments within the sessions are evidence that this unique composition of distributed humancomputer control, within community learning context and tool mediated communication enabled learning within the OICI. There was an overwhelming sense of the importance of interdependence of both humans and technology as illustrated in Agustina's reflection:

A great advantage of using the smartphone is that we can connect with many regions that we wouldn't normally be able to. For example - I can't go to Aceh and this normally means I can't know an Acehnese person. If I browse and find information about their culture, I can know about things that happen in that place. But the opportunity I get, even on the small screen (of my phone) brings amazing insight, I can see a person's manner and character/substance, I obtain what I need - a sense of knowing. The impact (of joining the collaborative inquiry) includes being able to socialize with others. There's no way I would have gained that without my smartphone - the phone enabled this. Yes, through our interactions we get to know others by their manner, behaviour, words and social communication.

These comments were accompanied by an awareness of the impact of human behaviour related to the use of computer Agustina requested additional reminders for all to go to location with good internet connectivity/signal to help with ensuring better collaboration. 
Proceedings of CHluXiD 2019 - The $5^{\text {th }}$ ACM In Cooperation International Conference in $\mathrm{HCl}$ and UX

\begin{tabular}{|c|c|c|}
\hline Forms of Communication & Planned Methodology & Actualised Details \\
\hline $\begin{array}{l}\text { Text and photo introductions } \\
\text { with Google Hangouts; } \\
\text { notification of session } \\
\text { schedule - Google } \\
\text { Hangouts }\end{array}$ & $\begin{array}{l}\text { Lead researcher work with } \\
\text { teachers to set up google } \\
\text { hangouts account and } \\
\text { encourage them to introduce } \\
\text { themselves there with text } \\
\text { and photos }\end{array}$ & $\begin{array}{l}\text { - } \quad \text { Most teachers sent introductory text and photos to class group. } \\
\text { - } \quad \text { nten needed to use Whatsapp (popular messaging app) to contact teachers as they didn't have } \\
\text { notifications turned on/didn't check google hangouts. Learning point for future activities - need to } \\
\text { step by step set up notification settings, some teachers sorted this out independently, many didn't } \\
\text { although prompted, this wasn't clear until interview. }\end{array}$ \\
\hline $\begin{array}{l}\text { Video conferencing with } \\
\text { Google Hangouts On Air } \\
\text { The lead researcher invites } \\
\text { teachers and once invited if } \\
\text { for any reason (internet } \\
\text { connectivity issues or } \\
\text { otherwise) participants can } \\
\text { rejoin without needing lead } \\
\text { researcher reissuing } \\
\text { invitation }\end{array}$ & $\begin{array}{l}\text { Teachers adapt their } \\
\text { communication to facilitate } \\
\text { being seen and known - lead } \\
\text { researcher giving initial } \\
\text { prompts regarding lighting } \\
\text { and face positioning in front of } \\
\text { camera }\end{array}$ & $\begin{array}{l}\text { - Sorting out 'joining' was frustrating for the lead researcher. Sometimes over } 45 \text { minutes with one } \\
\text { teacher. } \\
\text { All but two teachers successfully entered (device capacity limitations). } \\
\text { - The teachers were relaxed about engagement and use of technology in various venues including } \\
\text { walking along the street while in a hangout call. This relaxed engagement wasn't always optimal } \\
\text { for participation as a) background noises distracted others; b) internet connectivity not stable c) } \\
\text { visually face not centred or ineffective lighting - disrupted non-verbal communication and d) } \\
\text { teachers' concentration distracted in/by personal surroundings. } \\
\text { Many remarked seeing faces was important to sense of unity in diversity (underlying focus of } \\
\text { Pancasila inquiry). } \\
\text { Mobility bonus - sharing locations including classrooms. }\end{array}$ \\
\hline $\begin{array}{l}\text { Google Classroom } \\
\text { forum/digital library } \\
\text { Class code entry into was a } \\
\text { mandatory randomly given } \\
\text { combination of numbers and } \\
\text { letters (It would have been } \\
\text { preferable to have a } \\
\text { requested code to share) } \\
\text { Display arrangement able to } \\
\text { have 'theme' feeds but a little } \\
\text { clunky for searching through. } \\
\text { It would be interesting to } \\
\text { record times the photos or } \\
\text { videos were accessed - this } \\
\text { is possible in other apps but } \\
\text { not yet in google classroom. }\end{array}$ & $\begin{array}{l}\text { Teachers readily comment, } \\
\text { respond and add to } \\
\text { forum/digital library }\end{array}$ & $\begin{array}{l}\text { - } \\
\text { - } \quad \text { Within session teachers coached one another. With this support \& lead researcher assist many } \\
\text { teachers utilised the resources with their students (often sharing with a projector). Many teachers } \\
\text { commented about the unique benefit of having interregional resources from a 'real' friend, in } \\
\text { contrast to other unrelatable internet resources. Some teachers commented and asked questions } \\
\text { about the resources within Google Classroom but most comments and questions about the } \\
\text { resources were within synchronised sessions. } \\
\text { There were a few variances in mobile and PC operation - In PC version users can add multiple } \\
\text { videos/photos/docs to one post. In mobile version only one per post available. } \\
\text { A couple of teachers reported difficulty in posting on both PC and mobile. To share content, they } \\
\text { sent to lead researcher to post on their behalf. } \\
\text { With repeated prompting most teachers did complete a class 'assignment' sharing about } \\
\text { themselves. They were not able to see each other's comments until they had submitted their own. } \\
\text { This is quite different to social media apps such as Facebook and teachers found this limiting and } \\
\text { not inducive to interaction. } \\
\text { 'user friendliness' hindered teacher engagement on this app. It ended up acting mostly as a digital } \\
\text { library for those who wanted to find resources talked about in group video calls. It did not fulfil } \\
\text { envisaged asynchronous community interactions but did become a resource drawn upon by } \\
\text { teachers with a specific focus and with introduction within live video calls. }\end{array}$ \\
\hline Recorded sessions & $\begin{array}{l}\text { Design thought - recording } \\
\text { feature would benefit teachers } \\
\text { not able to attend. }\end{array}$ & $\begin{array}{l}\text { - Teachers absent to sessions didn't watch recordings. One exception - due to device/connectivity } \\
\text { related inability to join, this teacher ascribed great benefit from viewing (in contrast - other } \\
\text { absentees had scheduling conflicts and extra sessions (catch-ups) were held. } \\
\text { An unexpected benefit - several engaged teachers shared recordings with their students. }\end{array}$ \\
\hline $\begin{array}{l}\text { Google Profile } \\
\text { - to use google hangouts, an } \\
\text { email address is needed, } \\
\text { gmail is most efficient. } \\
\text { Generally, a profile displays a } \\
\text { photo and or a name for easy } \\
\text { identification. }\end{array}$ & $\begin{array}{l}\text { Teachers would be self- } \\
\text { motivated and able to set up } \\
\text { google profile. }\end{array}$ & $\begin{array}{l}\text { - All teachers had already set up gmail accounts on their phone - presumably for use of other apps. } \\
\text { However over half hadn't added a photo, and a third hadn't added name to user account. } \\
\text { - At least one teacher's 'gmail' account with their child's name brought confusion. } \\
\text { - } \\
\text { Retrospectively, take time to setting up Google profile would likely make sending video call } \\
\text { invitations easier and enable seeing who authored comments in Google Hangouts chat group. } \\
\text { - One teacher commented 'Sharing of members phone numbers is desired as 'it is more personal } \\
\text { and that in Google Hangouts we don't know who is online and who isn't. }\end{array}$ \\
\hline
\end{tabular}

Table 4. Negotiation of CHI Construct Communication - Proposed Format and Actualised Details.

Intan emphasised computer-human interdependence in achieving educational goals:

To be able to use the shared videos and photos was motivational and real. Even though we can get cultural resources from YouTube or elsewhere, it's like it's not us. It's like its somewhere else. But from our own google classroom, as I'm involved in it, I feel like, wow this is us, Indonesia, it's like this, and this and this, so I can encourage the children to know and be thankful and be passionate (about Indonesia). It's so amazing. Really! And hopefully all the archipelago friends will keep updating and videos and keep sharing!

Daniel shared about learning in CHI experience:

For google hangouts, this is a new thing for me, and google classroom it's new to me too. I think for the others it is also new. Maybe they're (google hangouts and google classroom) not yet popular to use here. I don't see a weakness with the applications, I haven't come across one. For strengths, it's almost the same as 'whatsapp' but 'whatsapp' can't facilitate lots of people, so the strength would be that it can facilitate lots of people in hangouts with video. I think hangouts is good but isn't popular yet. Also notifications don't pop up. There's no noise when there's a new message like in other apps.

(lead researcher shared that this is a user preference)

Oh, I have to change the setting to be able to see that? I thought it was automatic.

The teachers described the use of their phone with OICI setup as being: "very easy to use" (Am and Jay), "flexible" (Daniel and Yoni), "very practical, simple and hassle-free" (Iwan). Intan stated the OICI favourably compared to learning in study trips or other teacher professional development efforts she had participated in. The teachers mentioned that they were glad to be introduced to new apps on phone; some saying they had independently contacted one another outside of scheduled sessions and/or that they would use in future. They all shared that they were glad to meet their OICI colleagues online and learn together, stating they had become friends through the sessions. There was a consensus that the teachers would like to continue learning with this group as an OICI and for their local colleagues to have the opportunity to engage future OICIs. They mentioned they had gained much, with most listing their gains. Here's Jay's list: "significant insights, perspective, practical knowledge 
and a sense of support - not being alone with professional problems". The discussion was characterised as "exciting and relevant" (Komang), "sharing of relatable stories" (Yoni), "enriching" (Jay) "motivating and inspiring change" (Reza), "bringing about positive change in my relational behaviour that others have noticed" (Agustina), "a reference point" (Iwan) and "extremely necessary" (Rusna). Siti describes: "It's extremely good. It's where we can mutually exchange thoughts and work together. And get to know what other's perspectives are. And we can generate or realise perspective in the quest to know more. We more we deeply understand others through what is expressed. It's great learning from these friends. For example, when we discussed experiences of student theft". Yohana summarises "Even though we didn't directly meet, while we were talking, our eyes connecting, helped us to become endeared to each other".

In these comments it is clear that $\mathrm{CHI}$ facilitated exchange that supported interpretation of the Pancasila as unity in diversity. As the scope of this paper is to convey details of the teachers experience of $\mathrm{CHI}$, relating negotiation of control, context and communication occurring in the OICI, semiotics and meaning making are only briefly mentioned. These will be further discussed in future papers. Within the technology layer it is apparent that implicit and explicit positive and productive effects were $\mathrm{CHI}$ facilitated.

\section{DISCUSSION and PRELIMINARY FINDINGS}

The OICI evolved organically appropriate to the needs of teacher technology mediation and everyday living. Recruitment and engagement involved negotiating control, context and communication between teachers, lead researcher and technology, from proposed design to pragmatic function. The teachers' CHIs indicate that interpretative and critical stances were adopted to enable fluid engagement and meaningful contribution. Teacher comments and details of function convey the value of collaboration and importance of flexibility to harnessing of digital tools.

\section{Recruitment}

Teachers volunteered for recruitment after witnessing a focused presentation and personal interaction with lead researcher supported by regional contact persons. Physical and virtual (video call) presentation and interaction of the OICI opportunity were effective. Similarly setting up phones with Google Hangouts and Google Classroom was achieved through physically present and remotely assisted instruction. Ownership and capacity of smartphone was required for recruitment which inadvertently brought about less participation from older teachers. Three recruited teachers withdrew prior to commencing OICI due to change in status - one relating to professional employment status and two with private circumstances of wedding preparation and family death. Extra teachers were recruited by the teachers and the lead researcher to address the change and maintain representational design.

\section{Engagement}

Several teachers required perseverance and lead researcher assistance in 'invitation acceptance' to make affirmative response to security preferences that was exasperated by different language interfaces and confusion within the app itself. Google Hangouts On Air call from lead researcher was needed to incorporate stimulus of prepared modules in collaboration however when experiencing difficulty teachers sought to connect within the easily accessed Google Hangouts call that was limited to regular call (human and no screen sharing) collaboration. As this occurred the lead researcher would try to assist teachers to transition to the ongoing Google Hangouts on Air call. Three teachers were not able to fully engage in the Google Hangout On Air - one due to phone capacity and another extremely poor internet connectivity who withdrew and the other with mixture of phone use and low internet connectivity issues became a silent OICI member, viewing recorded sessions. Impromptu school and family commitments, illness, unsynchronised time-zones, uncommunicated variances in school hours, and weather and/or device performance effecting internet connectivity negatively impacted teacher engagement.

When teachers were successfully engaged, they were attentive and responsive to each other and content, even in the face of distracting background noises. Interview comments conveyed appreciation of being in the video call, especially commenting on the value of talking and seeing each other in real time and becoming friends. This emphasis of human-human relations is described by Jones, Ferreday and Hodgson [3] discussing computer supported collaborative learning approaches. Also, in this discourse, Hughes [10] describes the central task/need to build shared enterprise and identities emphasising role of structural design complimented by negotiation. In the OICI studied, engagement in video calls facilitated this need. Teacher's reflections on the asynchronous opportunities in Google Classroom recount use of resources linked to synchronously built relationships. Teacher comments on non-active notifications in both Google Classroom and Google Hangouts chatting feed along with lead researcher observations of underdeveloped identity impeding capacity to respond to a specific statement in Google Hangouts are likely the determinants of limited interactive asynchronous communication. Accordingly, beyond setting up the teachers' devices with Google Hangout and Google Classroom apps, the lead researcher surmises that setting up Google profiles before commencing inquiry; ensuring understanding and operation of mute control by all participants; and making notifications active for the apps, would likely support engagement further. This structured building of user identifiable profiles (in this case Google) with photos or at very least names, would fulfil Hughes' [10] prescription for relational recognisable diversity, supporting engagement.

Extra sessions were adding as teachers who had impromptu causes of absenteeism showed enthusiasm to join 
synchronous session but lack of interest in recorded sessions. This phenomenon is discussed by Choi and Chung [2] who note that acceptance of social network sites (SNS) [Google Hangouts can be regarded as a SNS] is unlike many other study settings where behaviour is largely dependent upon people's internal motivations. They assert that accepting and using SNS use is unique and is 'inherently related to other people' (p.7).

It was without hesitation, aligned to gotong royong ethos, that the teachers offered their digital devices and selves in response to the OICI opportunity. Kemp [13] reports $60 \%$ of the Indonesian adult population use internet capable phones. The teachers' comments relay that learning was enabled by their devices and convey the devices as seamless extensions of themselves. This reality of mobile devices enabling new contexts for learning [20]; with inquiry of the Pancasila being a centralised focus as prescribed by Söderström, Hamilton, Dahlgren and Hult's [27] is realising Valk, Rashid and Elder's [30] assertion that the growing field of mlearning (mobile learning) will overcome past delivery challenges of teacher professional development. This occurrence is similarly reported by Pachler et al [20 p.6] who assert that the mobile device's 'convergence of services and functions into a single device', 'ubiquity and abundance, portability and multi-functionality' bring about a shift where learners provide technical devices for learning. It is likely that further advances in technology will see increasingly sentient machinery with cognitive design [22] to facilitate identity sharing for ease of inviting to video call and recognition in asynchronous activities. Further desirable computer virtual partnering could bring about camera automatic manoeuvrability and auto lighting in video for better face positional and clear imagery, which were absent at times and may have enhanced experience in this OICI. Such advances could further support CHI to remove current constraints to non-verbal communication, to be a widespread engaging format for professional learning activities.

As noted from the outset, this paper is focused on the technological layer of tool mediated activity in the OICI. The semiotic layer and dialectical relationship of the two layers will be cogitated in future analysis and papers. This paper provides details of $\mathrm{CHI}$ negotiated control, communication and context that enabled OICI to take place. The harnessing of digital tools was responsive to needs. OICI engagement can be characterised as reciprocal and hero-ing Indonesian cooperative ethos and unity in diversity. The social dynamics described provide a snapshot of opportunities to promote $\mathrm{CHI}$ and constraining challenges to overcome.

\section{Limitations and Suggestions for future work}

This paper has explored CHI within the OICI of the Pancasila from the lead researcher's anecdotal observations of functionality and teachers' responses to open ended questions. It is noted that this study bears limited capacity to deeply analyse all $\mathrm{CHI}$ aspects occurring and possible. Focus on the constructs of control, context and communication provide insight to the structural design and associated negotiations of the technological layer of the teachers' mobile learning experience. The study has purposefully sought engagement of teachers as representatives of regional locations and subgroups of urban and rural, age, experience, school sector, gender and religion diversities. As the study was limited in resources and timing not all subgroups of Indonesia's vast population were able to be included.

The teachers' retrospective responses convey lingering impressions of the tool mediation rather than recording and diagnosing specifics of tools, technical problems and processes. Another area for further exploration is study of device make and model. A couple of teachers gave brief comments related to device capacity - one withdrew due to device issues in loading Google hangouts and no functionality to verbally contribute in the OICI synchronous sessions. Another teacher reported her device repeated crashed and shut down. Although no others recount their device crashing, it is possible device attributes such as ROM capacity and/or aerial/antennae strength impacted others experiences also. This may be relevant to software and hardware designers and advanced in a study intentionally focused on device capacity and tool mediation. It is apparent even in the comments specifically related to CHI shared in this paper that teachers were active in new ways of learning - characteristic of our mobile era - use of computational device (commonly utilised mobile phone) and learners being continuously on the move. Sharples et al [26] suggest that by engaging in new ways of learning, a tension with existing technologies and practices arises. More study is needed to investigate teachers' responses to rising tensions and forthcoming impact.

\section{Acknowledgements}

Thanks to the teachers who participated in this research and to supervisors and staff at CDU, RISTEKDIKTI, UPI and regional contacts who assisted with logistics enabling this research to take place and made time in their schedules.

\section{References}

1. Donna Bridges and Sharyn McGee. 2011. Collaborative inquiry. Creative Spaces for Qualitative Researching, pp. 213-222. Sense Publishers.

2. Gilok Choi and Hyewon Chung. 2013. Applying the Technology Acceptance Model to Social Networking Sites: Impact of Subjective Norm and Social. International Journal of Human Computer Interaction. doi:10.1080/10447318.2012.756333

3. Anthony P. Cocciolo. 2009. Using information and communications technologies to advance a participatory culture: A study from a higher education context. ProQuest, UMI Dissertations Publishing: 3368420

4. Amanda Datnow. 2011. Collaboration and contrived collegiality: Revisiting Hargreaves in the age of accountability. Journal of Educational Change, 12(2), 147-158. doi:10.1007/s10833-011-9154-1 
5. Jane L. David. 2009. Collaborative inquiry. Educational Leadership, 66(4), 87-88.

6. Siån Ede. 2005. Art and Science. I. B. Tauris. London

7. D. Randy Garrison. 2006. Online collaboration principles. Journal of Asynchronous Learning Networks, 10(1), 25-34.

8. D. Randy Garrison. 2012. Article review - Social presence within the community of inquiry framework. The International Review of Research in Open and Distributed Learning, 13(1), 250-253.

9. Delik Hudalah, Tommy Firman and Johan Woltjer. 2014. Cultural Cooperation, Institution Building and Metropolitan Governance in Decentralizing Indonesia. International Journal of Urban and Regional Research, 38(6), 2217-2234.

10. Gwyneth Hughes. (2007). Diversity, identity and belonging in e-learning communities: Some theories and paradoxes. Teaching in Higher Education, 12(5-6), 709-720. doi:10.1080/13562510701596315

11. Sunaryo Kartadinata. 2010. Etnopedagogik: Sebuah resureksi ilmu pendidikan (pedagogik). An article presented on the 2nd International Seminar 2010 Practice Pedagogic in Global Education Perspective. PGSD UPI, Bandung, 17 May 2010.

12. Elizabeth Kasl and Lyle Yorks. 2002. An extended epistemology for transformative learning theory and its application through collaborative inquiry. Teachers College Record, 2, 1-17.

13. Simon Kemp. 2018. Digital in 2018:World's Internet Users Pass the 4 Billion Mark. We Are Social [Blog post]. Retrieved from https://wearesocial.com/blog/2018/01/global-digitalreport-2018

14. Koentjaraningrat and Cornell University. Modern Indonesia Project. 1967. Villages in Indonesia. Cornell University Press.

15. Stein Kristiansen, and Pratikno. 2006. Decentralising education in Indonesia. International Journal of Educational Development, 26(5), 513-531. doi:10.1016/j.ijedudev.2005.12.003

16. Margaret Kumar. 2009. Postcolonial Theory and Cross-culturalism: Collaborative 'Signposts' of Discursive Practices. The Journal of Educational Enquiry, 1(2).

17. Yudi Latif. 2016. Pancasila And The Call for Social Justice. Retrieved from: http://www.fesindonesia.org/fileadmin/user_upload/events/2016/articl es/DrYudi_Latif_Pancasila_Welfare_State.pdf

18. Jean Lave and Etienne Wenger. 1991. Situated Learning: Legitimate Peripheral Participation. Oakleigh, Vic: Cambridge University Press.

19. Jean S. Mintz. 1961. Indonesia: A Profile (Vol. 3). Princeton, NJ: Van Nostrand.

20. Norbert Pachler, Ben Bachmair and John Cook. 2010. Mobile Learning Structures, Agency, Practices. New York: Springer.
21. Christine E. Pheeney and Helen Klieve. 2015. Investigating Social Media Potential for Teacher Learning in Aceh, Indonesia Proceedings of the International HCI and UX Conference in Indonesia (pp. 52-60). ACM Retrieved from http://dx.doi.org/10.1145/2742032.2742040

22. Mark Rolston. 2015, December 17th. The New Story of Computing: Invisible And Smarter Than You Retrieved from: https://www.fastcompany.com/3054733/thenew-story-of-computing-invisible-and-smarter-thanyou

23. Eunice Sari. 2012. Teacher professional development in an online learning community: A case study in Indonesia. Doctor of Philosophy Thesis: Theses: Doctorates and Masters. Paper 470. Retrieved from http://ro.ecu.edu.au/theses/470

24. Secretary Office Mental Revolution. 2016. Character Education as a base for Mental Revolution. Press Release. Retrieved from http://revolusimental.go.id/warta/berita

25. Elly M. Setiadi, Ida Rohayani, \& Christine E. Pheeney. 2017. Modul Pendidikan Resolusi Konflik: Modul Pembelajaran Guru Profesional. Bandung, Indonesia. Nomor: EC00201802698

26. Mike Sharples, Josie Taylor and Giasemi N. Vavoula. 2010. A theory of learning for the mobile age. In Medienbildung in neuen Kulturräumen, pp. 87-99. VS Verlag für Sozialwissenschaften.

27. Tor Söderström, David Hamilton, Dahlgren, Ethel and Agneta Hult. 2006. Premises, promises: Connection, community, and communion in online education. Discourse: Studies in the Cultural Politics of Education, 27(4), 533-549. doi:10.1080/01596300600988887

28. Edward W. Taylor, and Patricia Cranton. 2012. Handbook of Transformative Learning: Theory, Research, and Practice, 1 (Vol. 8). Hoboken: John Wiley \& Sons, Incorporated.

29. Technopedia. n.d. Mobile Application. Retrieved from: https://www.techopedia.com/definition/2953/mobileapplication-mobile-app

30. John-Harmen Valk, Ahmed Rashid and Laurent Elder. 2010. Using mobile phones to improve educational outcomes: An analysis of evidence from Asia. Canada: Pan Asia Networking, IDRC. Retrieved from http://www.irrodl.org/index.php/irrodl/article/view/794 /1487March -2010

31. Vientiane Seminar. 2003. Building the Capacities of Curriculum Specialists for Educational Reform in Asia. Final Report of the Regional Seminar, Vientiane, Lao PDR, International Bureau of Education \& UNESCO Asia and Pacific Regional Bureau for Education, Bangkok. Retrieved from http://portal.unesco.org/culture/en/files/22228/1091115 4713Building_Capacities.pdf/Building_Capacities 